\title{
CAUSAL SURVEY OF PURCHASE OF NON-LIFE INSURANCE PRODUCTS FOR LITHUANIAN CONSUMERS
}

\author{
Deimena KiyaK ${ }^{1}$, Linara Pranckevičiūté丶 ${ }^{2}$ \\ Klaipeda University (Lithuania)
}

\begin{abstract}
On purpose to increase the demand for insurance services in Lithuania there still remains a problem of how consumers perceive this service as well as what components, influencing their decision to purchase non-life insurance products, they accentuate in the price of insurance service. Emphasizing the assumptions of sustainable economic development in Lithuania and attempting to form regional policy by means of research, the study was implemented in order to identify factors and causal relationships that determine non-life insurance product purchasing motives in Lithuania. The study conducted a survey of Klaipeda city residents who buy various insurance products in different insurance companies. In total 420 respondents participated in this survey. To verify the results of the research three tests were applied: Pearson's Chi-square test, Fisher test (Fisher's exact) and Cramer's V test. It was identified that friends' recommendations do not affect consumer's choice for insurance products. Higher rates of benefits as well as flexible pricing policy were not important factors choosing an insurance company. High insurance product's cost and unclear conditions set in the contracts do not encourage consumers to purchase them. In the course of the research significant relationships between the consumer's choice to insure by specific insurance product and consumer's discount-enhanced motivation to purchase insurance products were not observed. All measured insurance products did not reflect statistically significant correlations between the decision to get insured and the knowledge about the prices in other insurance companies.

KEY WORDS: non-life insurance products, price, consumers' perceived value.
\end{abstract}

JEL CODES: C83; G 22; E30; L11; Y10; D46.

DOI: http://dx.doi.org/10.15181/rfds.v14i3.868

\section{Introduction}

Insurance and its associated processes are treated ambiguously by scientists due to the different points of view to this object (Čibinskienè, Činauskaitè, Navickas, 2005: 33). As stated by Narkūnienè and Stašys (2003: 79), insurance companies are important for both sides, i.e. the national economy and separate insurer.

The success of insurance business development is determined by companies' ability to focus on the relevant segments of insurers and efficiency in responding their insurance needs and expectations. Perceiving insurers, understanding their needs, expectations and behavioral patterns in the insurance market, insurance companies can take effective marketing actions and measures to encourage potential insurers to insure in their company, or change their behavior towards the direction desired by insurers (Kindurys, 2008: 52). The most significant participants in the insurance market are customers whose wishes and financial capacity

1 Deimena Kiyak - associate professor, Klaipėda University, Doctor of Economics Department. Social sciences, economy. Scientifically interests: finance, accounting, pricing, financial and economic analysis

E-mail: deimena.kiyak@gmail.com

Tel.: +370682 20253

2 Linara Pranckevičiūtė - PhD student, Social sciences, economy, Klaipėda University, Economics Department.

Scientifically interests: accounting, pricing, insurance, economic analysis

E-mail: linara.pranckeviciute@gmail.com

Tel.: +370652 24757 
allow insurance business to exist. Potential consumers of insurance services are critical for the insurance company, therefore, the success of any insurance business depends on the ability to focus on the relevant segments of the insurers and intelligently respond to their needs and expectations in regard to insurance services.

Problem. Insurance services - is one of the most complicated sort of services generally, as well as on the scale of all financial services that are relevant to them. Such service consumers face with perhaps one of the highest level of uncertainties regarding the service they pay for. For consumers it is actually difficult to understand the essence of insurance services and functioning of the mechanism, without having incurred property losses or collected information on insurance loss compensation subtleties (Ulbinaite, 2010: 1). The insurance services product main features include: the price (insurance premiums rate), covered insuring risks and insurance company's liability conditions (extreme conditions, exceptions and franchise).

According to V. Kindurys (2002), insurance services product price is the key thing of importance to most consumers of these services with the exception of experienced customers and financial institutions. Kiyak and Pranckevičiūte (2014) systematized the prices of Lithuanian insurance companies' sold non-life insurance types of products. The offers of the registered and operating non-life insurance companies in Lithuania examined in the price study were the following: AB "Lietuvos draudimas", UAB DK "PZU Lietuva", "ERGO Insurance SE" Lietuvos filialas, "IF P\&C Insurance" AS filialas, "BTA Insurance company" SE filialas, "SEESAM Insurance" AS filialas, "Compensa Towarzystwo Ubezpieczeń S.A." Vienna Insurance Group filialas, AAS "Gjensidige Baltic" Lietuvos filialas. The study showed that the insurance prices in different insurance companies differ significantly. The authors found that the compulsory motor third party liability insurance price in different companies ranges in 200-273 Lt limits. CASCO insurance product price fluctuations were especially vivid (in 666-1552 Lt limits). Property insurance rates are also markedly different - ranging between 261-570 Lt. In non-life insurance companies operating in Lithuania insurance against accidents prices varied even up to 5 times. At least prices differ in travel insurance offers. The most significant differences appeared in vehicle insurance as well as in the same kinds of insurance contributions in different companies. The data of insurance product prices analysis revealed differences in prices reaching up to 5 times of different insurance products operating in Lithuania in different non-life insurance companies. Frequent price fluctuations determined by the fact that different companies have different priority types of insurance lead to their competition in offering the best option for a minimum price for their customers. The essential conclusion affirmed that insurance products cannot be measured only in terms of price, as the product consists of the price as well as of the risks and benefits which are defined in the insurance contract.

Kiyak and Pranckevičiūtè (2014) comparing Lithuania's non-life insurance companies' product prices identified that the consumers find it difficult to choose them. Such difficulty is caused by a few reasons. First, insurance prices are strictly regulated by the Insurance Supervisory Authority, according to the company's technical reserves, but such information is only available to insurance companies and insurance brokers. Second, this analysis is quite difficult to perform because of the difficult calculations, although the price calculators are available on the websites of insurance companies. However, for the average consumer they are confusing, similarly to the insurance companies' product offers. The terminology used and the components of the contract, and the contract with the insurance-related conditions usually exceed the length of one page in the contracts. All the terms of the contract can only be found in a review of the insurance regulations related to the insurance contract. Insights in Kiyak and Pranckevičiūte’s (2014) study showed that frequently the inter-comparison of different companies' presented insurance product prices for the average consumer is even impossible.

Also Kiyak and Pranckevičiūte (2014) performed consumers' attitudes to non-life insurance products price survey and emphasized that consumers, choosing the insurer, pay attention not only to the price but also to such factors as prompt service, suitable ready settlement of claims, the insurance service after the acquisition of insurance, high-level personnel work. The authors identified that almost for a half of the surveyed respondents while insuring it is important whether the chosen company is socially responsible. Meanwhile, factors, such as loyalty to one company, known brand and the emotional satisfaction after the purchase, were of minor importance. 
Therefore, in order to increase the demand for insurance services in Lithuania a relevant problem to disclose how consumers perceive the service, what collectivity, economy, need existence, randomness, measurability and the risk signs they emphasize in the insurance services price, remains. This would allow insurance companies to review their pricing strategies, involving the application of product value theories in practical solutions, reducing the gap between the price paid and the value received.

The research object: the factors influencing consumers' decision to purchase non-life insurance products.

The aim of the research: to identify the factors and determine the causal relationships influencing non-life insurance product purchasing motives in Lithuania.

Research methodology. In order to identify consumers' attitudes to non-life insurance products price components the empirical study conducted Klaipeda city residents', who buy various insurance products in different insurance companies, survey. General population - Klaipeda city residents. According to the Department of Statistics established General population is 158541 residents. The survey sample was established in accordance with V. Dikčius (2006) recommended formula. In total 420 respondents participated in this survey. For the collection of the data a structured questionnaire was used (the majority of the questions included closed-ended type questions). The survey data was processed using SPSS.15 statistical data processing program, and MS Excel. For the evaluation of the research results three tests were used: Pearson Chi-square test, Fisher's exact, and Cramer's. V. Pearson Chi-square test was used to check hypothesis of independence of the two variables. The null hypothesis states that the features are independent, and the alternative states that there are features statistically significantly dependent (or in other words, statistically significant correlation between the analyzed features exists). The null hypothesis is rejected (i.e., statistically significant difference between the features exists), if the Pearson Chi-square test corresponding p-value is less than 0.05. Fisher's exact test is applied for the same purpose as the Pearson Chi-square, only gives more accurate results when both compared features gain 2 values only. The differences are statistically significant when the test $p$-value is less than 0.05 . Cramer's V test is also a Chi-square test analog, when two nominal features are being compared. There is a statistically significant relationship among the features, if the corresponding $\mathrm{p}$-value is less than 0.05 .

Research methods: examination of legislation, data collection, classification, grouping, collation, specification, elimination, generalization, systematization, interpretation, statistical methods, logical comparative analysis and synthesis.

\section{Non-life insurance product pricing theoretical aspects}

The most important insurance market participants are customers whose wishes and financial capabilities allow insurance business to exist. Potential consumers of insurance services are critical for the insurance company, so the insurance business success depends on its ability to focus on the relevant segments of the policyholders and intelligently meet their insurance needs and expectations. So the insurance companies, with a view to efficient and profitable operation must use sophisticated testing methods by which would be able to assess insurers' expectations and determine the reasons for their behavior (Lezgovko, 2010). Therefore, a specific product offered in the insurance market, the insurance service, which consumption price is insurance protection, making insurance benefits form, granting.

Insurance, as well as other purchases of services starts from the understanding the need for insurance. The appropriate type of insurance services will satisfy insurer's demands, which is directly related to the reduction of risk, because the insurer takes the policyholder's incurred risk. A policyholder does not realize insurance service's content and benefits while no real loss appears. Thus, the need for insurance services can lead to a variety of reasons for consumer behavior, involving the desire to feel safe and worry about the future, lifestyle, risk reduction or its management mode, binding laws and contractual requirements, or the view of insurance as an investment when the investment of insurance premiums helps to protect against major financial losses in the future (Kindurys, 2008: 57). 
Insurance products are among those which are difficult to sell their providers, and consumers find it difficult to use, i.e., consumers struggle understanding the risk they face, probabilities, it is difficult to correctly interpret, to evaluate and choose their price, quality, benefits, compare the products offered in the market, and etc.. The decision to purchase and to use insurance services, as well as the consumption itself are processes that arouse consumer's doubts and considerations (Ulbinaite, 2010: 5).

In the scientific literature, companies are advised to set prices according to the cost, consumer perceived value, the current price level (Christopher, 1982; Bakanauskas, 1997; Bakanauskas, Liesionis, 2002; Kotler, Keller, 2007; Rastenis, 2005; Barzdenytė, 2000). They also emphasize (Huber, Herrmann, Henneberg, 2007; Bakanauskas, 1997; Smith, Colgate, 2007; Khalifa, 2004; Dovalienė, 2005; Dovalienė, Viršilaite, 2008; Eggert, Ulaga, 2002), that, before determining the product price, companies have to find out whether the benefits provided by the product are equal to the benefits which the consumer desires to obtain.

Determining the price in terms of value, companies' prices must reflect how consumers evaluate a product or service. Consumers' decision to buy one or another product is influenced by their perception of the value they expect to get. A. Ravald, Ch. Gronroos (1996) argue that the value to the consumer - is the cost faced by consumers (price, service, risk of failure, the time spent by the user) for the purchase of service. A. Eggert, W. Ulaga (2002) received user benefits perceive as certain qualitative characteristics of services and servicing combination. A. S. Khalifa (2004) indicates that the user's perceived value is the maximum price that he is willing to pay for the economic and non-economic signs of the product. J. C. F. Roig, J. S. Garcia, M. A. M. Tena, J. L. Monzonis (2006) provide consumers' perceived benefits as three-dimensional (functional, social, emotional) mix that reflects the benefit for the consumer. As stated by R. Vaitkiene and V. Pilibaityte (2008) customer value is related to the relationship between the main product's produced tangible and intangible benefits and monetary and non-monetary cost of user-experience while acquiring the product. Other authors (Reddy, 1991; Snoj, 2004; Ge, 2002) define user's perceived value as the relationship between perceived benefits and perceived price. W. L. Chang and Y. T. Hong (2011) indicate that the value for the consumer is an assumption for all other values. V. Praude and E. Shalkovska (2009) delivering concept of the value identify three main components of the value for consumers: the user's benefit, the additional benefit for the user, user's costs incurred.

Value for the consumer can be considered the basis of all marketing decisions because providing greater value for the consumer is expected to be one of the most important competitive advantage and increase consumer loyalty factors (Dovalienè, 2005; Snieškienè, Pridotkienè, 2011). The company, in order to create greater value for the consumer, needs to understand how consumers perceive the value of their offer and make product proposal corresponding to the expectations (Kiyak, 2013).

\section{Consumers' non-life insurance products purchase reasons survey results} and discussion

The study sought to identify which aspects influence customers when choosing insurance products of the existing offers in Lithuanian market and what determinants operate making the decision to insure. One of the factors that may influence the decision to purchase insurance product in one or another insurance company was "recommendation of a friend". It was assessed that only $11.1 \%$ of respondents chose the purchase of the insurance product recommended by their friends in one or another insurance company. As Fisher's exact test statistical probability $p=0.035<0.05$, there is a statistically significant basis to state that friends' recommendations do not affect the respondents choice to purchase insurance products.

Bigger benefit rates and flexible pricing policy have not been identified as important factors for users that determine their choice for insurance products as well (see Table 1). 
Table 1. Bigger benefit payments and flexible price policy impact to insurance product selection test results

\begin{tabular}{|l|l|l|l|l|l|l|}
\hline \multicolumn{2}{|c|}{ Question } & No matter & $\begin{array}{c}\text { Neither important } \\
\text { nor does not matter }\end{array}$ & \multicolumn{1}{|c|}{ Important } & \multicolumn{1}{c|}{$\begin{array}{c}\text { Very } \\
\text { important }\end{array}$} & \multicolumn{1}{c|}{ Total } \\
\hline \multirow{2}{*}{ Bigger benefit payments } & No & $0 \%$ & $11.1 \%$ & $19.0 \%$ & $57.1 \%$ & $87.3 \%$ \\
\cline { 2 - 8 } & Yes & $1.6 \%$ & $1.6 \%$ & $4.8 \%$ & $4.8 \%$ & $12.7 \%$ \\
\hline Total & $1.6 \%$ & $12.7 \%$ & $23.8 \%$ & $61.9 \%$ & $100.0 \%$ \\
\hline \multirow{2}{*}{ Flexible pricing policy } & No & $0.0 \%$ & $12.7 \%$ & $17.5 \%$ & $57.1 \%$ & $87.3 \%$ \\
\cline { 2 - 8 } & Yes & $1.6 \%$ & $1.6 \%$ & $6.3 \%$ & $3.2 \%$ & $12.7 \%$ \\
\hline Total & $1.6 \%$ & $14.3 \%$ & $23.8 \%$ & $60.3 \%$ & $100.0 \%$ \\
\hline
\end{tabular}

Source: composed by authors

Statistical significance of these relationships are confirmed by Chi-square test statistical probability $p=0.037$ and $0.010<0.05$. The latter allows to presume that bigger benefit rates and flexible pricing policy do not affect the consumer's choice of the insurance company.

The objective of the study was to determine whether the insurance company's office equipped with modern interior design is an important factor for choosing the insurance. More than $80 \%$ of the respondents believe that this factor does not affect the decision whether to purchase insurance products (see Table 2).

Table 2. Beautiful and modern office factor importance when choosing an insurance product

\begin{tabular}{|l|l|l|l|l|l|l|l|}
\hline \multicolumn{2}{|c|}{ Question } & $\begin{array}{c}\text { No matter } \\
\text { at all }\end{array}$ & $\begin{array}{c}\text { No } \\
\text { matter }\end{array}$ & $\begin{array}{c}\text { Neither important } \\
\text { nor does not } \\
\text { matter }\end{array}$ & Important & $\begin{array}{c}\text { Very } \\
\text { important }\end{array}$ & Total \\
\hline \multirow{2}{*}{ Beautiful, modern office } & No & $25.0 \%$ & $25.0 \%$ & $25.0 \%$ & $5.0 \%$ & $3.3 \%$ & $83.3 \%$ \\
\cline { 2 - 10 } & Yes & $1.7 \%$ & $1.7 \%$ & $5.0 \%$ & $6.7 \%$ & $1.7 \%$ & $16.7 \%$ \\
\hline Total & $26.7 \%$ & $26.7 \%$ & $30.0 \%$ & $11.7 \%$ & $5.0 \%$ & $100.0 \%$ \\
\hline
\end{tabular}

Source: composed by authors

The statistical importance of this relationship is supported by Chi-square test statistical probability $p=0.023<0.05$, so there is a statistically relevant basis to say that beautiful office does not have impact on consumers' decision to buy an insurance product.

Even $45.2 \%$ of consumers claimed that high cost of insurance product does not encourage them to purchase voluntary motor insurance products, and $38.1 \%$ of the respondents indicated that the deterrent factor is unclear insurance conditions (see Table 3).

Table 3. Discouraging factors to purchase insurance products, test results

\begin{tabular}{|l|l|l|l|l|l|}
\hline \multicolumn{2}{|c}{ Question } & \multicolumn{1}{|c|}{$\begin{array}{c}\text { High cost of } \\
\text { insurance product }\end{array}$} & $\begin{array}{c}\text { Uncertain insurance } \\
\text { product conditions }\end{array}$ & $\begin{array}{c}\text { Such insurance is } \\
\text { not relevant to me }\end{array}$ & \multicolumn{1}{c|}{ Total } \\
\hline $\begin{array}{l}\text { Discouraging factors to } \\
\text { purchase CASCO insurance }\end{array}$ & No & $4.8 \%$ & $2.4 \%$ & $9.5 \%$ & $16.7 \%$ \\
\cline { 2 - 6 } & Yes & $45.2 \%$ & $38.1 \%$ & $0.0 \%$ & $83.3 \%$ \\
\hline Total & $50.0 \%$ & $40.5 \%$ & $9.5 \%$ & $100.0 \%$ \\
\hline
\end{tabular}

Source: composed by authors

A statistically significant correlation is approved by Chi-square test statistical probability $p=0.000<0.05$, which suggests, that high price of insurance products and its unclear acquisition conditions have a significant impact on consumers decision to insure. This relationship is strong and in Cramer's $V=0.727$, because the symmetrical dependence test statistical probability $p=0.000<0.05$.

Among the insured with property insurance, $9.5 \%$ of the respondents stated that high cost of insurance product does not encourage them to buy this insurance, and $23.8 \%$ of the respondents indicated that the deterrent factor is unclear insurance conditions of the products (see Table 4). 
Table 4. Factors discouraging to purchase property insurance

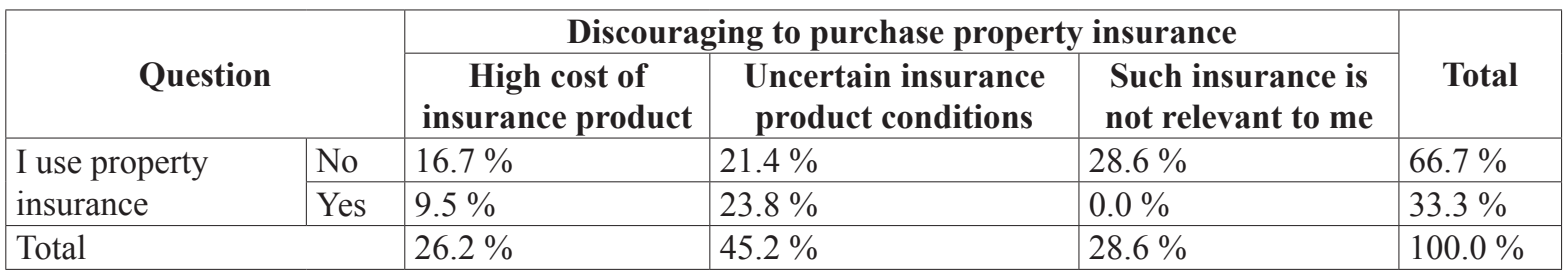

Source: composed by authors

Statistical essence of this relationship is confirmed by Chi-square test statistical probability $p=0.010<0.05$. The latter formula yet again verifies that uncertain security conditions and high cost of property insurance have impact on the consumer's choice of property insurance.

Assessing consumer satisfaction in non-life insurance products prices, it was determined that none of the insurance product has a statistically significant difference between the satisfaction levels which were given in the survey. That is, we cannot say that satisfaction of the cost of insurance affects user's willingness to insure a specific insurance product.

Significant dependencies were not determined while analyzing consumers' choices for insurance products to whether or not an insurance product price reflects its quality. It can be argued that there is no significant difference comparing consumers' choice to insure specific insurance product in the approach of how price of the product reflects its quality. In order to determine whether the discounts made encourage consumers to buy a particular insurance product, significant dependencies were not observed as well.

The study analyzed the influence of loyalty when choosing accident insurance, vehicle insurance, property insurance, travel insurance, third party liability insurance products. Evaluating members, insured CASCO insurance approach, it was found that $11.6 \%$ of the insured by this insurance believe that loyalty can be an aspect to be taken into account when calculating the cost of this kind of insurance (see Table 5). Meanwhile, between consumers who do not buy this insurance, even $50.7 \%$ believe that it is not a significant factor in calculating the cost of CASCO insurance (see Table 5).

Table 5. A relationship between aspect of loyalty and insurance product price results

\begin{tabular}{|l|l|l|l|l|}
\hline \multicolumn{2}{|c|}{ Question } & \multicolumn{2}{c|}{ Loyalty to the company } & \multirow{2}{*}{ Total } \\
\cline { 3 - 5 } \multicolumn{2}{|c|}{} & \multicolumn{1}{c|}{ No } & \multicolumn{1}{c|}{ Yes } & \\
\hline \multirow{2}{*}{ I use CASCO insurance } & No & $50.7 \%$ & $34.8 \%$ & $85.5 \%$ \\
\cline { 3 - 5 } & Yes & $2.9 \%$ & $11.6 \%$ & $14.5 \%$ \\
\hline Total & No & $53.6 \%$ & $46.4 \%$ & $100.0 \%$ \\
\hline \multirow{2}{*}{ I use travel insurance } & Yes & $43.5 \%$ & $23.2 \%$ & $66.7 \%$ \\
\hline Total & $10.1 \%$ & $23.2 \%$ & $33.3 \%$ \\
\hline
\end{tabular}

Source: composed by authors

The statistical importance of this relationship is confirmed by Fisher's Exact test statistical probability $p=0.037<0.05$. Therefore it can be claimed that the inclusion of loyalty as a component into the price formula of CASCO insurance would not affect the respondents' who do not buy insurance CASCO decision to purchase it. Loyalty, as one of the possible aspects calculating the price, appeared to be a significant factor between respondents who have opted for travel insurance. $23.2 \%$ of all respondents insured by travel insurance believe that loyalty is an important aspect evaluating the cost of this kind of insurance (see Table 5). The statistical prominence of this relationship is embodied in Fisher's Exact test statistical probability $p=0.010<0.05$. Therefore, there is a statistically significant basis for the statement that involving loyalty as one of the pricing aspects into prices' spreadsheets should affect consumers' choice in travel insurance. 
The study found that education, as one of the pricing aspects, is an important factor between respondents who have opted for travel insurance. The majority, i.e. $52.2 \%$ of all respondents do not use this insurance and do not think that it is important. Meanwhile, among the insured persons, $18.8 \%$ believe that this is an important aspect (see Table 6). Statistical relevance of this relationship is confirmed by Fisher's Exact test statistical probability $p=0.006<0.05$.

Table 6. Importance of education as a pricing aspect for respondents who purchase travel insurance

\begin{tabular}{|l|l|l|l|l|}
\hline \multicolumn{2}{|c|}{ Question } & \multicolumn{2}{c|}{ Education } & \multirow{2}{*}{ Total } \\
\cline { 3 - 6 } & \multicolumn{2}{c|}{ No } & \multicolumn{1}{c|}{ Yes } & \\
\hline \multirow{2}{*}{ I use travel insurance } & No & $52.2 \%$ & $14.5 \%$ & $66.7 \%$ \\
\hline Total & Yes & $14.5 \%$ & $18.8 \%$ & $33.3 \%$ \\
\hline
\end{tabular}

Source: composed by authors

Respondents insured by property insurance showed a tendency of pursuit of optimum variant between the protection granted, and the price paid for it. The percentage of such respondents comprised $27.5 \%$ of all insured by property insurance (see Table 7). The statistical significance of this relationship is justified by Fisher's Exact test statistical probability $p=0.015<0.05$.

Table 7. Importance of search of a variant of optimal protection and price for consumers buying property insurance

\begin{tabular}{|c|c|c|c|c|}
\hline \multirow{2}{*}{\multicolumn{2}{|c|}{ Question }} & \multicolumn{2}{|c|}{$\begin{array}{l}\text { I always try to find optimum variant between granted } \\
\text { protection and the price paid for it }\end{array}$} & \multirow[t]{2}{*}{ Total } \\
\hline & & No & Yes & \\
\hline \multirow{2}{*}{ I use property insurance } & No & $23.2 \%$ & $47.8 \%$ & $71.0 \%$ \\
\hline & Yes & $1.4 \%$ & $27.5 \%$ & $29.0 \%$ \\
\hline \multicolumn{2}{|l|}{ Total } & $24.6 \%$ & $75.4 \%$ & $100.0 \%$ \\
\hline
\end{tabular}

Source: composed by authors

The influence of the insured person's independence on the choice of insurance mode is reflected in Table 8. It is noted that in most cases customers choose insurance companies independently or partially independently. A similar trend is observed among respondents who choose insurance brokers. Meanwhile, internet is usually chosen by respondents who consider themselves exclusively independent. The statistical importance of this relationship is confirmed by Fisher's Exact test statistical probability $p=0.036<0.05$. Therefore there are statistically significant grounds to assert that the presence of independence influences respondents in their choice of insuring online.

Table 8. Influence of the policyholder's independence on the choice of insurance mode

\begin{tabular}{|c|c|c|c|c|c|}
\hline \multirow{2}{*}{\multicolumn{2}{|c|}{ Question }} & \multicolumn{3}{|c|}{$\begin{array}{l}\text { I am independent, for me it is easy and convenient } \\
\text { to order services myself, and therefore pay less }\end{array}$} & \multirow[t]{2}{*}{ Total } \\
\hline & & I agree & Partially agree & I do not agree & \\
\hline \multirow{3}{*}{ I usually insure } & $\begin{array}{l}\text { In the insurance } \\
\text { company }\end{array}$ & $25.8 \%$ & $21.0 \%$ & $6.5 \%$ & $53.2 \%$ \\
\hline & I use insurance brokers & $16.1 \%$ & $8.1 \%$ & $11.3 \%$ & $35.5 \%$ \\
\hline & Via internet & $11.3 \%$ & $0.0 \%$ & $0.0 \%$ & $11.3 \%$ \\
\hline \multicolumn{2}{|l|}{ Total } & $53.2 \%$ & $29.0 \%$ & $17.7 \%$ & $100.0 \%$ \\
\hline
\end{tabular}

Source: composed by authors 
Among the respondents, who prefer broker services, a clearly distinguished inclination to purchase faceto-face with the seller appears. This type of respondents amounted $29.5 \%$ of all examined (see Table 9).

Table 9. The relationship between the pursuit of direct communication and choice of insurance brokers' services

\begin{tabular}{|c|c|c|c|c|c|}
\hline \multirow{2}{*}{\multicolumn{2}{|c|}{ Question }} & \multicolumn{3}{|c|}{$\begin{array}{l}\text { I like to purchase services dealing directly with } \\
\text { the seller, so I agree to pay slightly more }\end{array}$} & \multirow[t]{2}{*}{ Total } \\
\hline & & I agree & Partially agree & I do not agree & \\
\hline \multirow{2}{*}{ Do you use insurance brokers' services } & Yes & $29.5 \%$ & $11.5 \%$ & $9.8 \%$ & $50.8 \%$ \\
\hline & No & $13.1 \%$ & $14.8 \%$ & $21.3 \%$ & $49.2 \%$ \\
\hline \multicolumn{2}{|l|}{ Total } & $42.6 \%$ & $26.2 \%$ & $31.1 \%$ & $100.0 \%$ \\
\hline
\end{tabular}

Source: composed by authors

The statistical relevance of this relationship is approved by Fisher's Exact test statistical probability $p=$ $0.034<0.05$, therefore, there exist statistically significant grounds to claim that direct communication with the seller affect respondents to choose insurance brokers' services, i.e., those who like to purchase directly communicating with the sellers often choose insurance brokerage services.

It can be seen that among those who insure themselves against accidents, the major part are respondents with higher income (more than $2000 \mathrm{Lt}$ ), that is $17.7 \%$ of all respondents. Among those who do not purchase this insurance, the greater part is represented by people with lower than $2000 \mathrm{Lt}$ income, that is $47.1 \%$ of all respondents (see Table 10).

Table 10. Influence of family income on the selection of insurance against accidents

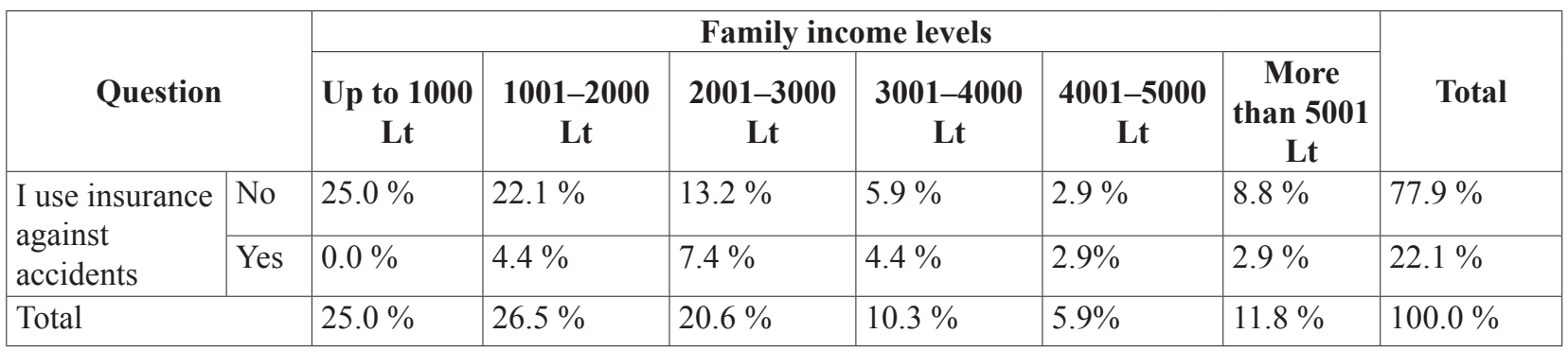

Source: composed by authors

The statistical importance of this relationship is justified by Fisher's Exact test statistical probability $p=$ $0.023<0.05$. Accordingly, there are statistically significant features to claim that family income has impact on respondents' choice to buy insurance against accidents, i.e., those who have higher income insure against accidents more frequently.

Observing relationships between travel insurance and education, it is clear that respondents with higher education use travel insurance more frequently. The percentage of respondents with secondary education who opted for travel insurance was only $4.3 \%$, while of those having a university degree $-20.3 \%$ (see Table 11 ).

Table 11. Influence of education on travel insurance purchase

\begin{tabular}{|l|l|l|l|l|l|l|}
\hline \multirow{2}{*}{ Question } & \multicolumn{5}{c|}{ Education } & \multicolumn{1}{c|}{ Total } \\
\cline { 3 - 7 } \multicolumn{2}{|c|}{} & $\begin{array}{c}\text { Secondary } \\
\text { education }\end{array}$ & $\begin{array}{c}\text { Professional } \\
\text { qualification }\end{array}$ & $\begin{array}{c}\text { Higher education in } \\
\text { acquisition }\end{array}$ & $\begin{array}{c}\text { University } \\
\text { education }\end{array}$ & \\
\hline $\begin{array}{l}\text { I use travel } \\
\text { insurance }\end{array}$ & No & $24.6 \%$ & $11.6 \%$ & $10.1 \%$ & $20.3 \%$ & $66.7 \%$ \\
\cline { 2 - 7 } & Yes & $4.3 \%$ & $1.4 \%$ & $7.2 \%$ & $20.3 \%$ & $33.3 \%$ \\
\hline Total & $29.0 \%$ & $13.0 \%$ & $17.4 \%$ & $40.6 \%$ & $100.0 \%$ \\
\hline
\end{tabular}

Source: composed by authors 
The statistical significance of this relationship is confirmed by Fisher's Exact test statistical probability $p=0.031<0.05$, so there is a statistically significant basis to assert that education has impact on respondents' choice to buy travel insurance, i.e., those who have higher education, are more common customers of travel insurance.

\section{Conclusions}

The study showed that friends' recommendations have no influence on the choice of insurance products. Higher benefit rates and flexible pricing policy are also not important elements choosing an insurance company. High cost of the insurance product and unclear conditions in the insurance product purchase contract do not encourage consumers to purchase motor third party liability and property insurance. Moreover, the study did not reveal significant relationships between consumer's choice to insure a specific insurance product and consumer's encouragement to purchase insurance products using offered discounts. As well no inter-correlations between the decision to insure and familiarity with other companies' prices were noticed. Loyalty as a potential component for CASCO insurance cost calculation is irrelevant for respondents who do not buy such insurance. Meanwhile, respondents insured by travel insurance believe that loyalty is an important factor assessing the cost of this insurance. It was assessed that education, as one of the aspects of insurance pricing, was an important factor for travel insurance consumers. Property insurance consumers aim to find optimal variant between the protection granted and the price paid for it. The consumers who find themselves independent enough are inclined to purchase insurance products on the internet, whereas insurance brokerage services are more prevalent among customers with a marked feature of direct communication with the seller. Accordingly, the latter mentioned insurance brokers' customers expect to save and pay less for insurance. Consumers with higher income are inclined to insure against accidents more frequently, similarly to how respondents with higher education are more likely to purchase travel insurance.

\section{References}

Bakanauskas, A. (1997). Vertès samprata kainodaroje. Ekonomika ir vadyba'97, Nr. 1, p. 22-23.

Bakanauskas, A., Liesionis, V. (2002). Kaštų - vertès kainos nustatymo modelis Žaliojo marketingo komplekse. Organizaciju vadyba: sisteminiai tyrimai, Nr. 1, p. 21-32.

Barzdenytė, B. (2000). Kainodara ir konkurencija. Vilnius: Vilniaus universiteto leidykla.

Chang, W. L., Hong, Y. T. (2011). A mixture model to estimate customer value for e - services. Kybernetes, Vol. 40, No. $1 / 2$, p. 182-199.

Christopher, M. (1982). Value - in - use pricing. European Journal of Marketing, Vol. 16, p. 35-46.

Čibinskienè, A., Činauskaitè, J., Navickas, V. (2005). Draudimo paslaugų industrija: formavimasis bei plètra. Organizaciju vadyba: sisteminiai tyrimai, Nr. 34, p. 33-41.

Dikčius, V. (2006). Marketingo tyrimai: teorija ir praktika. Vilnius: Vilniaus vadybos aukštoji mokykla.

Dovalienè, A. (2005). Santykiu marketingo ypatumai plètojant teatro produktu rinką. Daktaro disertacija. Socialiniai mokslai, vadyba ir administravimas.

Dovalienè, A., Virvilaitè, R. (2008). Vertè vartotojui ir jos svarba santykių su paslaugų teikèju ilgalaikiškumui: teatro sektoriaus atvejis. Inžinerinè ekonomika, Nr. 1 (56), p. 66-73.

Eggert, A., Ulaga, W. (2002). Customer perceived value: a substitute for satisfaction in business markets? Journal of Business \& Industrial Marketing, Vol. 17, No. 2/3, p. 107-118.

Ge, D. (2002). Value pricing in presence of network effects. Journal of Product \& Brand Management, Vol. 11, No. 3, p. $174-185$.

Huber, F., Herrmann, A., Henneberg, S. C. (2007). Measuring customer value and satisfaction in services transactions, scale development, validation and cross-cultural comparison. International Journal of Consumer Studies, Vol. 31, p. 554-564.

Khalifa, A. S. (2004). Customer value: a review of recent literature and an integrative configuration. Management decision, Vol. 42, No. 5, p. 645-666.

Kiyak, D. (2013). Produkto vertès sampratos koncepcija kainodaros procese. Regional formation and development studies. Journal of Social Sciences, No. 1 (9), p. 79-93. 
Kiyak, D., Pranckevičiūtè, L. (2014). Draudimo produktų kainų palyginamoji analizè. Regional formation and development studies. Journal of Social Sciences, No. 2 (13), p. 43-57.

Kiyak, D., Pranckevičiūtè, L. (2014). Vartotojų suvokiamos draudimo produktų kainos tyrimas. Management Theory and Studies for Rural Business and Infrastructure Development, Vol. 36, No. 3, p. 534-546.

Kindurys, V. (2002). Draudimo paslaugų marketingas. Monografija. Vilnius: Vilniaus universiteto leidykla.

Kindurys, V. (2008). Teoriniai draudejjų elgsenos tyrimo aspektai ir jos apraiškos Lietuvos gyvybės draudimo paslaugu rinkoje. Ekonomika, Nr. 81, p. 52-73.

Kotler, P., Keller, K. L. (2007). Marketingo valdymo pagrindai. Klaipedda: Logitema.

Lezgovko, A. (2010). Draudimo ekonomikos pagrindai. Klaipeda: Klaipédos universiteto leidykla.

Narkūniené, J., Stašys, R. (2003). Lietuvos draudimo rinkos plètros problemos ir perspektyvos. Tiltai, Nr. 2 (23), p. 79-84.

Praude, V., Shalkovska, E. (2009). Marketing factors of formation of company's customer equity. Organizaciju vadyba: sisteminiai tyrimai, Nr. 52, p. 63-75.

Rastenis, J. (2005). Kainodara. Kaunas: Technologija.

Ravald, A., Gronroos, Ch. (1996). The value concept and relationship marketing. European Journal of Marketing, Vol. 30, No. 2, p. 19-30.

Reddy, N. M. (1991). Defining product value in industrial markets. Management Decision, Vol. 29, No. 1, p. 14-19.

Roig, J. C. F., Garcia, J. S., Tena, M. A. M., Monzonis, J. L. (2006). Customer perceived value in banking servines. International Journal of Bank Marketing, Vol. 24, No. 5, p. 266-283.

Smith, J. B., Colgate, M. (2007). Customer Value Creation: A Practical Framework. Journal of Marketing Theory and Practice, Vol. 15, No. 1, p. 7-23.

Snieškiene, G., Pridotkienè, J. (2011). Eksporto kainodaros tikslų ir jiems poveikị darančių aplinkos veiksnių vertinimas Lietuvos eksportuotojų pavyzdžiu. Ekonomika ir vadyba, Nr. 16, p. 359-365.

Snoj, B., Korda, A. P., Mumel, D. (2004). The relationships among perceived quality, perceived risk and perceived product value. Journal of Product \& Brand Management, Vol. 13, No. 3, p. 156-167.

Ulbinaité, A. (2010). Vartotojų elgsenos ypatumų draudimo paslaugų vartojimo atžvilgiu teoriniai aspektai. Business Management and Education. Conference paper. Vilnius: VGTU. Available at: http://leidykla.vgtu.lt/conferences/ BME_2010/007/pdf/Art-Ulbinaite-Vartotoju.pdf

Vaitkiené, R., Pilibaitytè, V. (2008). Vertès vartotojui kūrimo ir santykių su vartotojais vystymo procesus integruojantis modelis. Applied Economics: Systematic Research, Vol. 2, p. 45-57.

\title{
NE GYVYBÉS DRAUDIMO PRODUKTU PIRKIMO PRIEŽASČIU TYRIMAS
}

\author{
Deimena Kiyak, Linara Pranckeviččūtė \\ Klaipėdos universitetas (Lietuva)
}

\section{Santrauka}

Draudimo paslaugos yra vienos sudėtingiausių paslaugų tiek tarp bendrai visų paslaugų, tiek ir tarp joms artimų finansinių paslaugų. Šių paslaugų vartotojai bene labiausiai jaučia tam tikrą paslaugų, už kurias jie moka, netikrumą. Paprastai suvokti draudimo paslaugos esmę ir paslaugos funkcionavimo mechanizmą, nepatyrus nuostoliu ir nesurinkus informacijos apie draudimo nuostolio kompensavimo subtilybes, vartotojams iš tiesų yra sunku. Prie draudimo paslaugų produkto pagrindinių savybių priskiriama: jo kaina (draudimo įmokos tarifas), padengiamos draudžiamos rizikos ir draudimo įmonès atsakomybės sąlygos (ypatingos sąlygos, išimtys ir franšizè).

Todẻl siekiant Lietuvoje didinti draudimo paslaugų paklausą išlieka aktuali problema atskleisti, kaip vartotojai suvokia šią paslaugą, kokius kolektyviškumo, ekonomiškumo, poreikio egzistavimo, atsitiktinumo, išmatuojamumo ir tos pačios rizikos egzistavimo požymius akcentuoja rinkdamiesi draudimo paslaugos kainą. Tai leistų draudimo paslaugų bendrovėms peržiūrèti savo kainodaros strategijas, įtraukiant produktų vertės teorijų taikymą priimant praktinius sprendimus, mažinant atotrūkị tarp mokamos kainos ir gaunamos 
vertès. Tyrimo tikslas - nustatyti veiksnius ir priežastinius ryšius, kurie lemia ne gyvybės draudimo produkto pirkimo motyvus Lietuvoje.

Siekiant identifikuoti vartotojų požiūrio ị ne gyvybès draudimo produktų kainų dedamąsias, atliekant empirinį tyrimą, atlikta Klaipėdos miesto gyventojų, perkančių skirtingus draudimo produktus skirtingose draudimo bendrovėse, apklausa. Generalinė visuma - Klaipėdos miesto gyventojai. Remiantis Statistikos departamento pateiktais duomenimis, nustatyta generalinè visuma - 158541 gyventojas. Iš viso tyrime dalyvavo 420 respondentų. Duomenims rinkti pasirinkta struktūruota anketinė apklausa (dauguma anketos klausimų - uždarieji). Anketinès apklausos būdu gauti duomenys apdoroti naudojant SPSS.15 statistinę duomenų apdorojimo programą ir MS EXCEL programą. Tyrimo rezultatams patvirtinti taikyti trys testai: Pearson Chi kvadrato testas, Fisherio testas (Fisher's exact) ir Cramer's $V$.

Atliktas tyrimas atskleidè, kad draugų rekomendacijos neturi jokios įtakos renkantis draudimo produktus. Didesni išmokų tarifai ir lanksti kainų sistema taip pat nėra reikšmingi veiksniai, renkantis draudimo bendrovę. Aukšta draudimo produkto kaina ir neaiškios draudimo produkto sąlygos neskatina vartotojų ịsigyti TPVCA ir turto draudimą. Tyrimo metu nenustatyta reikšmingų ryšių tarp vartotojų pasirinkimo pirkti konkretų draudimo produktą ir vartotojų skatinimo įsigyti draudimo produktą ịvairiomis akcijomis. Lojalumas, kaip vienas iš aspektų, lemiančių KASKO draudimo kainą, nesvarbus respondentams, kurie nesidraudžia šiuo draudimu. Tuo tarpu kelionių draudimu besidraudžiantys respondentai mano, kad lojalumas yra svarbus aspektas ịvertinant šio draudimo kainą. Nustatyta, kad išsilavinimas, kaip vienas draudimo kainos nustatymo aspektų, buvo svarbus veiksnys tarp kelionių draudimą pasirinkusių respondentų. Respondentams, kurie draudžiasi turto draudimu, ypač svarbu atrasti optimalų variantą tarp teikiamos apsaugos ir už ją mokamos kainos. Savarankiškais save laikantys vartotojai linkę pirkti draudimo produktus internetu. Tuo tarpu tie, kurie mėgsta pirkti tiesiogiai bendraudami su pardavėju, dažniau renkasi draudimo brokerių paslaugas. Be to, rinkdamiesi draudimo brokerių paslaugas vartotojai tikisi sutaupyti ir mokèti už draudimą mažiau. Didesnes pajamas gaunantys vartotojai labiau linkę draustis nuo nelaimingų atsitikimų, o aukštesnị išsilavinimą turintys respondentai labiau linkę draustis kelionių draudimu.

PAGRINDINIAI ŽODŽIAI: ne gyvybès draudimo produktai, kaina, vartotojų suvokiama vertè.

JEL KLASIFIKACIJA: C83; G 22; E30; L11; Y10; D46. 